\title{
NOMINAL LEXEMES MORPHEMES REDUPLICATION OF MANDARIN
}

\author{
Shi Yuxin \\ (Universitas Gadjah Mada/ shi.yuxin.0214@gmail.com)
}

\begin{abstract}
Morphologically, functions of Chinese reduplication may place categorically within the derivational domain of lexemes. In fact, whereas derivation typically forms new lexemes and can be category changing, reduplication often conveys values typically found in the inflectional domain. By using the test of categorical word and test of lexical decomposition, this research achieves shed new light on the reduplicative processes. As a result, in the nominal domain, reduplication gives as a result plural noun. In the derivational domain, nominal lexeme in reduplication has a flexible distribution of lexical items. In this case, the types of reduplication of noun in Mandarin show the process of $A A, A A B$, and $A A B B$ patterns.
\end{abstract}

Keywords:

Nominal Lexemes; Derivational; Mandarin; Reduplication

DOI: 10.19105/ojbs.v13i2.2504

\section{A. Introduction}

Mandarin is spoken around Beijing and forms the basis of the country's national language. ${ }^{1}$ Reduplication is one of the most productive word formation phenomena in Mandarin, as we will see throughout this research. Reduplication in Mandarin is a creative phenomenon, virtually affecting all major lexical categories (nouns, verbs, adjectives). This research will investigate one of lexeme in these lexical categories, nominal lexeme.

Typologically, Rubino lists two types of reduplication are distinguished

\footnotetext{
${ }^{1}$ Harimurti Kridalaksana, Kamus Linguistik (Jakarta: Gramedia, 2008), 205.
}

based on the size of the Chinese reduplicant: full reduplication and partial reduplication. ${ }^{2}$ Full reduplication involves a reduplication of the entire word. ${ }^{3}$ Full word lexical reduplication: 年 nián 'year' becomes 年年 nián nián 'every year'. Reduplicated monosyllabic nouns like 年

\footnotetext{
2 Carl Rubino, 'Reduplication: Form, Function and Distribution', in Studies on Reduplication (Berlin, Boston: De Gruyter, 2005), 13, https://doi.org/10.1515/9783110911466.11.

${ }^{3}$ Full Reduplication is also called Complete (total) Reduplication, it happens when both the parts have meanings and are meaningful, as quoted by Shivani Sachdeva and Ashwani Sethi, 'A Tool to Search and Convert Reduplicate Words from Hindi to Punjabi', IJERA: International Journal of Engineering Research and Applications 4, no. 8 (August 2014): 32.
} 
年 nián nián are abbreviated as $\mathrm{AA}$ pattern. Partial reduplication involves a reduplication of only part of the word. It can be the initial phoneme (either consonant or vowel or syllable) of the base which was substituted by another phoneme or syllable. ${ }^{4}$ For example, 毛雨 máo yŭ' drizzle (dialect language, informal)' becomes 毛毛雨 máo máo yŭ ' drizzle (formal)'. Reduplicated monosyllabic nouns like 毛毛雨 máo máo yǔ are abbreviated as AAB pattern.

Chinese reduplication syllables are usually facilitated as symbols $A$ and symbol $B$, symbol $A$ is used for the first syllable in reduplication, symbol ' $\mathrm{B}$ ' is used to express the second syllable consisting of two syllables. Research on reduplication pattern (except semantic reduplication patterns) in Chinese is determined by Chinese scholars: AA pattern, AAB pattern, ABB pattern, BBA pattern, AABB pattern, $A$ li $A B$ pattern, and $A B A B$ pattern.

Based on the data examined, patterns relate to reduplication of nouns are AA pattern, AAB pattern and AABB pattern. The examples are as follow:

1. AA pattern: 年 nián 'year' becomes 年 年 nián nián 'every year'; and 杠 gàng 'underline' becomes 杠杠 gàng gàng means 'underlines'.

2. $A A B$ Pattern: 毛雨 máo yŭ drizzle (informal) becomes 毛毛雨 máo máo yǔ

${ }^{4}$ Mohd Imran Kahn, 'Reduplication in Arabic and Urdu', International Journal of English and Education 5, no. 4 (October 2016): 338. 'drizzle'; 窝头 wō tóu 'local bread (informal)' becomes 窝窝头 wō wō tóu 'steamed corn bread'.

3. Pola AABB: 坑洼 kēng wā ' hole' becomes 坑坑洼洼 kēng kēng wā wā' holes'; 里外 lǐ wài 'outside and inside' becomes 里里外外lǐ lǐ wài wài 'from inside to outside'.

From cases above, some problems are caused by the reduplication process. In the case (3) above, lexeme 里 外 lǐ wài and 坑洼 kēng wā are both nominal domain, and equally duplicated with the AABB pattern, the reduplicative meanings which are resulted from these two words are totally different. As for disyllabic reduplicated nouns 坑坑洼洼 kēng kēng wā wā, the disyllabicity of the base 坑洼 kēng wā point to uncontroversial nominal bases. But category 里外 lǐ wài is changed by AABB pattern. Reduplication of 里外/I wài 'outside and inside' is 里里外外 lǐ lǐ wài wài 'from inside to outside', which manifests property of lexeme formation and, formally, approaches derivational phenomena of reduplication.

Actually, while derivation typically forms new lexemes can change category and lexical meaning, reduplication often conveys values typically found in the inflectional domain. ${ }^{5}$ Functions of reduplication are difficult to place categorically within the derivational domain of lexemes. But reduplication

5 J.W.M Verhaar, Pengantar Linguistik (Yogyakarta: Gadjah Mada University Press, 1983), 152-53. 
changes category like the examples in (1) and (3). For investigate these derivational phenomena in Mandarin, this research will focus to find what meaning can be associated various forms of reduplication which is formed by nominal lexeme, and after observing the change of category and lexical meaning we will address the issue of whether reduplicative proses applies to derivational process or inflectional process.

Reduplication in Mandarin called 叠 词 dié cí. According to 新华字典 xīn huá zì diăn (Mandarin Dictionary) defined as 'Reduplication is the process of repeating words or elements'. ${ }^{6}$

To analyze reduplication in Mandarin, the concepts and theories need to be explained here. Chǔ Zéxiáng, The Principle of Complementary Distribution of Chinese Morphological Reduplication and Syntactic Reduplication defined reduplication in Mandarin as (1) repetition; (2) reduplication; (3) and repetitive clause. $^{7}$ Phonological reduplication or repetition has no basis. Meaning does not have a basic word, some examples are given by Zéxiáng, 孜孜 $z \bar{\imath} z \bar{l}$ means 'diligently' in the Mandarin language, but

${ }^{6}$ Wèi Jiàngōng and Xiāo Jiālín, Xīn Huá Zi Diăn (Kamus Besar Bahasa Mandarin) (Beijing: The Commercial Press, 2012), 325.

7 Chǔ Zéxiáng, 'Hàn Yǔ Gòucíchóng Diéyǔ Gòu Xíng Chóng Dié de Hù Bǔ Fēn Bù Yuán Zé (The Principle of Complementary Distribution of Chinese Morphological Reduplication and Syntactic Reduplication)', World Chinese Teaching 7 (2018): 173-83.
孜 $z \bar{\imath}$ is not a meaningful morpheme. ${ }^{8} \mathrm{~A}$ repetitive clause is a phrase or clause repeated in a sentence, for example '没有, 没有。'méi yǒu méi yǒu means 'no, no'. The repeated element is a clause.

Lǐ yàn lists that nouns, verbs, and adjectives are often developed with certain additional restriction. ${ }^{9}$ At the level of syntax, words and their development can be called phrases in Mandarin. Because of this, noun reduplication analysis needs to be distinguished from phrases through their forms, for example 棒棒糖 bàng bàng táng 'Iollipop' consists of the adjective 棒棒 bàng bàng 'with a stick / stem' + 糖 táng 'candy / sugar' becomes 棒棒 糖 bàng bàng táng 'candy stick' is a compound phrase or word that looks like an AAB pattern.

The cases of Chinese reduplication have been investigated by some researchers, as Bodi Jin, through his thesis, he studied about all kinds of reduplication patterns either full or partial reduplication of modern Chinese and classical poetry. He found that there are similarities and dissimilarities in terms of meaning effect and structure between Shijing (modern Chinese) and Tang Poetry (Classical poetry), it indicated that some features of reduplication of classical poetry is changing overtime. ${ }^{10}$ Another

\footnotetext{
8 Zéxiáng, 173-83.

${ }^{9}$ Lǐ Yàn, 'Lùn Xiàndài Hànyǔ $A A B$ Shì Chóngdié (Analisis Reduplikasi Pola AAB)' (Universitas Normal Xuzhou, 2010), 55-57.

10 Bodi Jin, 'Reduplication in Classical Chinese Poetry' (Thesis, Universiteit Leiden, 2018), 41.
} 
research is done by Liu, he investigated about the adjectives of Chinese words that are reduplicated, the pattern used were $A A$ (or $X X)$, AABB (XXYY), and $A B B$ (XYY) patterns. ${ }^{11}$ In line with Liu, Lee-Kim also studied about adjective reduplication, he noted that subordinate compounds of adjective that follow the form of $A B$ are reduplicated as $\mathrm{ABAB}$, and coordinate compounds of the same form reduplicated by following AABB pattern. ${ }^{12}$

Those few studies mostly used adjectives. There has been limited reduplication of noun that was analyzed. This current study aims to add the evidence of Mandarin reduplication by analyzing the nominal lexemes morphemes reduplication.

\section{B. Method}

This research investigates the derivational reduplication in Mandarin. The derivation sometimes changes the categorical base word. Therefore, it's necessary to check if the reduplication of nouns is derivational and inflectional. Two tests will be used as proposed by Verhaar, (1) test of categorical word; (2) test of lexical decomposition. ${ }^{13}$

11 Chen-Sheng Luther Liu, 'Reduplication of Adjectives in Chinese: A Default State', Journal of East Asian Linguist 22 (2013): 102, https://doi.org/10.1007/s10831-012-9099-2.

12 Sang-Im Lee-Kim, 'Syntax-Based Phonological Asymmetries: The Case of Adjective Reduplication in Mandarin Chinese', Lingua 179 (August 2016): 1, https://doi.org/10.1016/j.lingua.2015.12.015.

${ }^{13}$ Verhaar, Pengantar Linguistik, 152-53.
Test (1) can be used to determine whether reduplication is derivational or paradigmatic/ inflectional, using observational techniques to observe the property of the relevant base word. Derivation typically forms new reduplication and can be category or lexical meaning changing. If reduplication doesn't make a change in the categorical base word, the resulting categorical reduplication is the same as the categorical base word base word, test (1) can't be used and test (2). And if duplicated noun does not display changing property, which means that is inflectional reduplication.

\section{Results}

\section{Nominal bases + AA Pattern}

Monosyllabic bases can reduplicate as $A$ becomes AA. Nouns can reduplicate in Mandarin, delivering an entire increasing function, although these $A A$ reduplications no longer seem to be creative. Furthermore, reduplicated monosyllabic nouns are stated to have a distributive ${ }^{14}$ or plural collective. ${ }^{15}$

\footnotetext{
${ }^{14}$ Charles N. Li and Sandra A. Thompson, Mandarin Chinese. A Functional Reference Grammar (Barkeley: University of California Press, 1981); Dan $\mathrm{Xu}$, Plurality and Classifiers Accross Languages in China (Berlin: Mouton de Gruyter, 2012).

15 Paris in Chiara Melloni and Bianca Basciano, 'Reduplication Across Boundaries: The Case of Mandarin', in Encyclopedia of Chinese Language and Linguistics (Leiden: Brill, 2017).
} 


\section{2. 'Every or Each': Noun Quantifier + AA Pattern}

AA pattern are productive with nominal bases. However, whether or not the AA pattern seems to depend on the meaning and the semantic characteristics of the bases, only nominal bases that have a noun quantifier (noun has quantificational meaning) can contain $A A$ pattern with the meaning 'every or each'. ${ }^{16}$

a. 年nián 'year' > 年年 nián nián ' every year';

b. 家 jiā 'family' > 家家 jiā jiā ' every family';

c. 天tiān 'day' > 天天 tiān tiān 'every day';

d. 月yuè 'month' > 月月yuè yuè 'every month';

e. 岁suì 'year (old)' > 岁岁 suì suì 'every year'.

As shown by the cases above (a) -(e), where each of reduplication contains the quantifier 每 měi 'every or each'. Going back to research topic, reduplication of monosyllabic nouns proper expresses a 'every or each' meaning, which manifests property of lexeme, and some of categorical bases have been changed. As Verhaar's test of lexical decomposition said, derivation typically forms new lexeme can change lexical meaning of bases. Reduplicative

\footnotetext{
${ }^{16}$ Wú yín, 'Shìlùnmíngcí $A A B B$ Shì Yǔfǎ Yìyì Jíqítā (Analisis Arti Gramatikal dan Hal Lain yang Bersangkutan Reduplikasi Pola AABB Kata Benda)', Yǔwén Yánjiū, 2001, 13-15.
}

process noun quantifier + AA pattern is a derivational process. ${ }^{17}$

\section{3. 'Plural' on AA Pattern}

Reduplication is attested with a variety of meanings. This phenomenon is associated with its prototypical function of intensification. $^{18}$ In its, the nominal, reduplication gives as a result plural noun, this may show one of the reduplicative values in Mandarin:
a. 星 xīng 'star' > 星星 xīng xīng 'stars';
b. 杠 gàng 'line' > 杠杠 gàng gàng 'lines'.

The data above show that duplicated noun does not display changing property, reduplication 星星 xīng xīng 'stars' and relevant base 星 xing 'star' has the same category status.

\section{Nominal Lexeme + AABB Pattern}

Disyllabic bases can reduplicate as $A B$ becomes $A A B B$. As we have seen, reduplicated monosyllabic nouns have 'every/ each' or 'plural' meaning. In fact, disyllabic nouns have 'plural' meaning too, and 'every/ each' meaning more varied at AABB pattern. Reduplicated monosyllabic nouns are known as have a distributive meaning. ${ }^{19}$

\footnotetext{
${ }^{17}$ Verhaar, Pengantar Linguistik, 152-53.

18 Abd. Ghofur, Madurese and English Morphology (The Process \& Differences) (Surabaya: Pena Salsabila, 2013).

19 yín, 'Shìlùnmíngcí AABB Shì Yǔfă Yìyì Jíqítā (Analisis Arti Gramatikal dan Hal Lain yang Bersangkutan Reduplikasi Pola AABB Kata Benda)', 13-15; Susumu Ikeda, 'Activation of the Stativity in Chinese AABB Type Noun Reduplication Forms', Bulletin of Chinese Linguistics 8, no. 2 (2015): 292-
} 


\section{5. 'Distributive' on AABB Pattern}

As for disyllabic reduplicated nominal lexeme, the disyllabicity of the base point to uncontroversial nature nominal bases.

a. 年岁 nián suì 'year' > 年年岁岁 nián nián suì suì 'every year';

b. 分秒 fēn miăo 'minute' > 分分秒秒 fēn fēn miăo miăo 'every minute';

c. 村寨 cūn zhài 'village' > 村村寨寨 cūn cūn zhài zhài 'every village';

d. 里外 lǐ wài 'inside outside' > 里里外外li lĭ wài wài 'from inside to outside';

e. 上下 shàng xià 'top bottom' > 上上下下 shàng shàng xià xià from top to bottom';

f. 风雨 fēng yǔ 'problem (metaphor)' > 风 风雨雨 fēng fēng yǔ yǔ 'problems';

g. 瓶罐 píng guàn 'bottle' > 瓶瓶罐罐 píng píng guàn guàn 'bottles';

h. 坑洼 kēng wā 'hole' > 坑坑洼洼 kēng kēng wā wā 'holes'.

As we have seen in above cases, some very flexible lexical items seem to indicate distributive meaning. These reduplications can function either as an argument or as an adverbial. As we have seen in example (a), (b) and (c), reduplication of disyllabic units does not have distributive meaning, while the second contains the quantifier 每 měi 'every or each'. Providing a detailed

95, https://doi.org/10.1163/2405478X-00802007; Zhāng lìshēng, 'Xiàn Dài Hàn Yǔ Míng Cí de AABB Fù Dié Shì (Analisis Pengulangan Pola AABB Kata Benda)', Xúzhōu Shïfàn Dàxué Xué, 1999, 59-60. distributive meaning expressed by reduplicated classifiers is beyond the scope of this research. So, what we want to explain is that it is not easy to draw a clear meaning.

Going back to research topic, categorical bases have been changed by reduplicative process in cases (a)--(c). Reduplicative process noun + AABB pattern is a derivational process.

\section{6. 'Plural' on AABB Pattern}

As shown in (6)--(8), above show that duplicated noun does not display changing property, reduplication 风风雨雨 fēng fēng yǔ yǔ and relevant base 风雨 fēng yŭ has the same category status. Reduplicated monosyllabic nouns can be said that there are no all reduplicative processes noun + AABB pattern are derivational process. A 'plural-collective meaning' means reduplicative processes noun + AABB pattern may has an inflectional marking. ${ }^{20}$

In addition, there are some idiomatic reduplications are formed by $A A B B$ pattern, the possible bases for $A A B B$ reduplication are either lexicalized, nontransparent bases (a), or adjectives constructed by two morphemes with a similar meaning in cognitive level (b):

a. 风火 fēng huǒ the literal meaning is wind and fire;

20 Marie-Claude Paris, "Un Aperçu de La Réduplication Nominale et Verbale En Mandarin," Faits de Langue 29 (2007): 65-76. 
b. 风风火火 fēng fēng huǒ huǒ used for metaphorically in a hurry and reckless, etc.

A similar meaning or a logical coordination like case (a) and (b) is not easy to translate. As Kridalaksana said, idiomatic reduplication cannot be translated from repeated forms. ${ }^{21}$

\section{Function 'Formalize' on AAB Pattern}

Disyllabic bases can reduplicate as AB becomes AAB. Nouns can reduplicate in Mandarin, delivering an entire increasing function, although these are very low number of $A A B$ reduplications, and that no longer seem to be creative:

a. 尧板 qiào băn 'see saw (Shuzhou dialect)' > 跷跷板 qiào qiào băn 'see saw';

b. 毛雨 máo yŭ ' drizzle (Yangzhou dialect)' > 毛毛雨 máo máo yŭ ' drizzle';

c. 窝头 $w o \bar{o}$ tóu 'steamed corn bread (Peking)' > 窝窝头 wō wō tóu 'steamed corn bread'.

The basic words and the resulting reduplications are categorical nouns, reduplicative process does not make a categorical change, and it does not even change the lexical meaning even though its form has changed.

According to Goldberg, different surface forms are typically associated with slightly different semantic or discourse

${ }^{21}$ Kridalaksana, Kamus Linguistik, 280. functions. ${ }^{22}$ From the example above, the function that can be caused by the ABB pattern is 'formalizing', for example 跷踾板 qiào qiào băn compared to 翅 板 qiào băn, 跷䠤板 qiào qiào băn will be more formal than 趐 qiào băn, and 跷跷板 qiào qiào băn can be viewed in the dictionary. Here presumably the dialect language works side by side to influence the development of Mandarin reduplication that is a kind of variation or system in Mandarin.

Based on the data examined, in addition to isolating meanings and figurative meanings, as we have shown with the reduplicative processes of Mandarin as we have shown with the reduplicative processes of Mandarin, nouns as basic words, the meanings and functions increased by reduplication of $A A$ patterns, $A A B$ patterns and AABB patterns in Mandarin are as follows:

a. To reduplicate nouns AA nouns, AABB patterns can result in the meaning of 每 měi 'every or each'. Meanwhile, the basic words are the same as having quantification characteristics:

1) 年 nián 'year' > 年年 nián nián 'every year';

2) 天 tiān 'day' > 天天 tiān tiān 'every day';

3) 村寨 cūn zhài 'village' > 村村寨寨 cūn cūn zhài zhài 'each of village'.

22 Adele E Goldberg, 'Constructions: A New Theoretical Approach to Language', Trends in Cognitive Sciences 7, no. 5 (May 2003): 221, https://doi.org/10.1016/S1364-6613(03)00080-9. 
b. Basic word of a noun after following AABB pattern can have meaning "From $A$ to B", and the basic nouns are about direction. For instance:

1) 里外 lǐ wài 'inside and outside' > 里 里外外 lǐ lǐ wài wài 'from inside to outside.'

2) 上下shàng xià 'top and bottom'. >上 上下下shàng shàng xià xià 'from top to bottom.'

3) 前后 qián hòu 'front and back' > 前前 后后 qián qián hòu hòu 'from front to back.'

c. Basic word that is not "the direction" or "the quantification" also potential to be undergone $\mathrm{AA}$ pattern and $\mathrm{AABB}$ pattern, and the meaning is "plural". For example:

1) 杠 gàng 'underline' > 杠杠 gànggàng 'underlines.'

2) 坑洼 kēng wā 'hole' > 坑坑洼洼 kēng kēng wā wā 'holes.'

d. One of the functions of reduplication pattern of $A A B$ for basic word of a noun is to "formalize it", for example 翘板 qiào băn 'seesaw' (Shuzhou dialect) becomes 跷跷板 qiào qiào băn 'seesaw". In this case, 踾跣板 qiào qiào băn is more formal than just 尧树板 qiào băn although it has the same meaning.

If the concept of lexeme arises empirically motivated in agglutinating languages whereby inflection markers modify the word form conveying relevant aspect in the syntactic contexts, its motivation is less grounded in isolating languages, where words occur with a very small number of inflection markers.

Now this research focuses on the categorical status between the reduplication and relevant base address the issue of whether reduplicative process

Table 1

Derivational and Inflectional Morphemic Reduplication (Nominal lexemes)

\begin{tabular}{|c|c|c|c|c|c|c|c|c|}
\hline \multicolumn{2}{|c|}{ Reduplication } & \multicolumn{3}{|l|}{ Input } & \multicolumn{3}{|l|}{ Output } & \multirow{2}{*}{$\begin{array}{l}\text { Morphemic } \\
\text { Process }\end{array}$} \\
\hline Pattern & Meaning & Basic Word & $\begin{array}{l}\text { Lexical } \\
\text { Meaning }\end{array}$ & $\begin{array}{l}\text { Lexical } \\
\text { Category }\end{array}$ & Reduplication & $\begin{array}{l}\text { Lexical } \\
\text { Meaning }\end{array}$ & $\begin{array}{l}\text { Lexical } \\
\text { Category }\end{array}$ & \\
\hline AA & 'plural' & $\begin{array}{l}\text { 杠 } \\
\text { gàng }\end{array}$ & underline & Noun & $\begin{array}{l}\text { 杠 杠 } \\
\text { gàng gàng }\end{array}$ & underlines & Noun & Inflection \\
\hline AA & 'every’ & $\begin{array}{l}\text { 天 } \\
\text { tiān }\end{array}$ & day & Noun & $\begin{array}{l}\text { 天天 } \\
\text { tiān tiān }\end{array}$ & every day & Adverbial & Derivation \\
\hline AABB & 'every' & $\begin{array}{l}\text { 村寨 } \\
\text { cūn zhài }\end{array}$ & village & Noun & $\begin{array}{l}\text { 村村寨寨 } \\
\text { cūn cūn zhài } \\
\text { zhài }\end{array}$ & $\begin{array}{l}\text { every } \\
\text { village }\end{array}$ & Noun & Derivation \\
\hline AABB & 'plural' & $\begin{array}{l}\text { 坑洼 } \\
\text { kēng wā }\end{array}$ & hole & Noun & $\begin{array}{l}\text { 坑坑洼洼 } \\
k \bar{e} n g \text { kēng wā } \\
\text { wā }\end{array}$ & holes & Noun & Inflection \\
\hline AABB & 'from $A$ to $B$ ' & $\begin{array}{l}\text { 上下 } \\
\text { shàng xià }\end{array}$ & $\begin{array}{l}\text { top and } \\
\text { bottom }\end{array}$ & Noun & $\begin{array}{l}\text { 里里外外 } \\
\text { lí lǐ wài wài }\end{array}$ & $\begin{array}{l}\text { from top to } \\
\text { bottom }\end{array}$ & Adverbial & nflection \\
\hline
\end{tabular}

OKARA: Jurnal Bahasa dan Sastra, Vol. 13, No. 2, November 2019 
applies to derivational processes or inflectional processes. Reduplication in Mandarin conveys values typically found in the inflectional domain.

The data of all nominal lexemes reduplication of Mandarin can be seen in the table above.

\section{Conclusion}

This research has given the extreme variety of forms, meanings and functions. base nouns meanings and types of reduplicative noun in Mandarin This research would have explained the reduplicative process of forming $A A$ pattern, $A A B$ pattern, and $A A B B$ pattern.

\section{References}

Ghofur, Abd. Madurese and English Morphology (The Process \& Differences). Surabaya: Pena Salsabila, 2013.

Goldberg, Adele E. 'Constructions: A New Theoretical Approach to Language'. Trends in Cognitive Sciences 7, no. 5 (May 2003): 219-24.

https://doi.org/10.1016/S13646613(03)00080-9.

lìshēng, Zhāng. 'Xiàn Dài Hàn Yǔ Míng Cí de AABB Fù Dié Shì (Analisis Pengulangan Pola AABB Kata Benda)'. Xúzhōu Shîfàn Dàxué Xué, 1999, 58-62.

Ikeda, Susumu. 'Activation of the Stativity in Chinese AABB Type Noun Reduplication Forms'. Bulletin of
Chinese Linguistics 8, no. 2 (2015): 289-300. https://doi.org/10.1163/2405478X00802007.

Jiàngōng, Wèi, and Xiāo Jiālín. Xīn Huá Zì Diăn (Kamus Besar Bahasa Mandarin). Beijing: The Commercial Press, 2012.

Jin, Bodi. 'Reduplication in Classical Chinese Poetry'. Thesis, Universiteit Leiden, 2018.

Kahn, Mohd Imran. 'Reduplication in Arabic and Urdu'. International Journal of English and Education 5, no. 4 (October 2016): 336-44.

Kridalaksana, Harimurti. Kamus Linguistik. Jakarta: Gramedia, 2008.

Lee-Kim, Sang-Im. 'Syntax-Based Phonological Asymmetries: The Case of Adjective Reduplication in Mandarin Chinese'. Lingua 179 (August 2016): 1-23. https://doi.org/10.1016/j.lingua.201 5.12.015.

Li, Charles N., and Sandra A. Thompson. Mandarin Chinese. A Functional Reference Grammar. Barkeley: University of California Press, 1981.

Liu, Chen-Sheng Luther. 'Reduplication of Adjectives in Chinese: A Default State'. Journal of East Asian Linguist 22 (2013): 101-32. https://doi.org/10.1007/s10831012-9099-2.

Melloni, Chiara, and Bianca Basciano. 'Reduplication across Boundaries: The Case of Mandarin'. In 
Encyclopedia of Chinese Language and Linguistics. Leiden: Brill, 2017.

Paris, Marie-Claude. 'Un Aperçu de La Réduplication Nominale et Verbale En Mandarin'. Faits de Langue 29 (2007): 65-76.

Rubino, Carl. 'Reduplication: Form, Function and Distribution'. In Studies on Reduplication. Berlin, Boston: De Gruyter, 2005. https://doi.org/10.1515/978311091 1466.11.

Sachdeva, Shivani, and Ashwani Sethi. 'A Tool to Search and Convert Reduplicate Words from Hindi to Punjabi'. IJERA: International Journal of Engineering Research and Applications 4, no. 8 (August 2014): 31-35.

Verhaar, J.W.M. Pengantar Linguistik. Yogyakarta: Gadjah Mada University Press, 1983.

$\mathrm{Xu}$, Dan. Plurality and Classifiers across Languages in China. Berlin: Mouton de Gruyter, 2012.

Yàn, Lǐ. 'Lùn Xiàndài Hànyŭ $A A B$ Shì Chóngdié (Analisis Reduplikasi Pola AAB)'. Universitas Normal Xuzhou, 2010.

yín, Wú. 'Shilùnmíngcí $A A B B$ Shì Yŭfă Yìyì Jíqítā (Analisis Arti Gramatikal dan Hal Lain yang Bersangkutan Reduplikasi Pola AABB Kata Benda)'. Yǔwén Yánjiū, 2001, 1216.

Zéxiáng, Chǔ. 'Hàn Yǔ Gòucíchóng Diéyǔ Gòu Xíng Chóng Dié de Hù Bǔ
Fēn Bù Yuán Zé (The Principle of Complementary Distribution of Chinese Morphological Reduplication and Syntactic Reduplication)'. World Chinese Teaching 7 (2018): 173-83.

OKARA: Jurnal Bahasa dan Sastra, Vol. 13, No. 2, November 2019 